Marquette University

e-Publications@Marquette

Finance Faculty Research and Publications

Finance, Department of

4-1-2015

The Effects of Securities Class Action Litigation on Corporate Liquidity and Investment Policy

Matteo P. Arena

Marquette University, matteo.arena@marquette.edu

Brandon Julio

London Business School

Accepted version. Journal of Financial and Quantitative Analysis, Vol. 50, No. 1-2 (April 2014):

251-275. DOI. (C) 2014 Cambridge University Press. Used with permission. 


\title{
The Effects of Securities Class Action Litigation on Corporate Liquidity and Investment Policy
}

\author{
MATTEO ARENA* \\ Marquette University \\ BRANDON JULIO ${ }^{\dagger}$ \\ London Business School
}

November 2012

\begin{abstract}
The risk of securities class action litigation alters corporate savings and investment policy. Firms with greater exposure to securities litigation hold significantly more cash in anticipation of future settlements and other related costs. The result is due to firms accumulating cash in anticipation of lawsuits and not a consequence of plaintiffs targeting firms with high cash levels. The market value of cash is significantly lower for firms exposed to litigation risk. Corporate investment decisions are also affected by litigation risk, as firms reduce capital expenditures in response. Our results are robust to endogeneity concerns and possible spurious temporal effects.
\end{abstract}

*Department of Finance, Marquette University, 312 Straz Hall, P.O. Box 1881, Milwaukee, WI 53201-1881; emailmatteo.arena@marquette.edu; phone: (414) 288-3369.

†Department of Finance, London Business School, Regent's Park, London NW1 4SA, United Kingdom; email: bjulio@london.edu, phone: +44 (0)20 7000 8254. We thank Pat Akey, Alan Crane, Vito Gala, LiuLing Liu, Andrew Roper, Vikrant Vig, Olga Yakusheva, and seminar participants at Marquette University, the 2010 Financial Management Association Conference, and the 2011 Oklahoma Risk Management Conference for helpful comments. 
The rights of shareholders, from the basic right to vote to replace directors to the right to sue for damages in a court of law, are widely recognized as being important for the efficient allocation of capital through an economy. However, the incentives created by granting strong legal rights to investors may change firm behavior in unintended ways. In this paper, we investigate how the securities litigation environment in the US affects corporate liquidity policy and investment decisions. We find that firms significantly alter their cash holdings and investment policy to manage litigation risk.

Under the Securities Acts of 1933 and 1934, all publicly listed firms in the United States are exposed to the risk of security class action lawsuits. Despite the passing of the Private Securities Litigation Reform Act of 1995, which intended to make it more difficult to initiate shareholder lawsuits by requiring plaintiffs to provide proof that executives intentionally defrauded investors, the incidence of securities lawsuit filings has increased (Choi, Nelson, and Pritchard (2009)) and corporate lawsuit costs have remained high (Karpoff, Lee, and Martin (2006)). As Zingales (2006) indicates, the total dollar value of lawsuit settlements totaled \$9.7 billion in 2005. Given the potential size of lawsuit settlements, litigation risk has important implications for expected cash flows.

Exposure to securities litigation risk affect firms in various ways, both directly and indirectly. Firms at higher risk of litigation underprice their IPOs relatively more as a form of insurance (Lowry and Shu (2002)) and are more likely to undertake aggressive growth through acquisitions (Gormley and Matsa (2009)). Litigation risk affects firms' disclosure behavior (Skinner (1994)). Auditors shy away from corporate clients at risk of litigation and charge higher fees (Shu (2000)).

One corporate policy that may be particularly sensitive to litigation risk is the decision to accumulate cash flow in the form of liquid assets. Bolton, Chen and Wang (2011) present a dynamic model of investment, financing and risk management in which the firm uses both a state-noncontingent vehicle (cash) and state-contingent contracts to manage exposure to systematic and idiosyncratic risk. In their model, financial hedging and liquidity management are complementary tools in risk management. When dynamic hedging has high transactions costs, the firm relies more on increasing cash and scaling back investment for hedging risk. Similarly, Froot and Stein (1998) model a firm's risk management choices in a world in which 
some risks cannot be perfectly hedged in the capital market. In this framework, firms face a trade-off between managing risk by entering hedging transactions and managing risk through capital structure choices. If it is difficult or costly to hedge a particular type of risk, firms will instead adopt a more conservative capital structure by accumulating a cash buffer.

We hypothesize that litigation risk is an important determinant of a firm's decision to hold cash. Due to the costs associated with raising external finance and the possibility of future cash flow shocks, firms have an incentive to save more cash to avoid raising external capital to finance new investments and other corporate activities (Lins, Servaes, Tufano (2010)). Thus, we expect that, all else equal, firms with higher exposure to litigation risk will hold more cash on their balance sheets in anticipation of future settlement costs and other indirect costs associated with litigation. We also examine whether the accumulation of cash due to litigation risk exposure has an impact on firms' real investment decisions.

Consistent with Bolton, Chen and Wang (2011), in addition to accumulating cash, firms enter into state-contingent insurance contracts to protect themselves from the direct costs of litigation risk. Almost all public firms in the U.S. buy A-side or B-side insurance to indemnify officers or directors 1 Many firms buy also optional entity securities coverage (C-side insurance). Such coverage provides protection for the corporation for its own liability. However, litigation insurance does not provide full coverage in many cases. According to the annual Towers Perrin Directors and Officers Liability Surveys, public firms have an average litigation insurance limit of about $\$ 15$ million over our sample period (1996-2006). The average settlement amount in our sample is more than three times larger (\$56 million) than the average litigation insurance limit 2 However, the distribution of settlement amounts is highly skewed due to several very large payouts in our sample. The median settlement amount is $\$ 6.5$ million. Even though according to Towers Perrin about $85 \%$ of public firms in the U.S. bought some C-side insurance in 2006, only about 50\% firms had C-side coverage at the beginning of our sample period. Additionally, insurance cannot offer protection from the indirect costs of litigation. Based on settlements costs, the percentage of US firms buying C-side insurance,

\footnotetext{
${ }^{1} \mathrm{~A}$-Side coverage provides coverage directly to the directors and officers for loss resulting from claims made against them for their wrongful acts. A-Side Coverage applies in cases when the corporation does not indemnify its directors and officers. B-side coverage reimburses a corporation for its loss if the firm indemnifies its directors and officers for claims against them.

${ }^{2}$ The actual total litigation cost for the average firm is larger when accounting for legal fees.
} 
and the average annual litigation insurance limit, the aggregate net-of-insurance settlement cash outflows for US publicly-traded firms in our sample is approximately 2.2 billion dollars per year during our sample period. Based on annual insurance data in the Towers Perrin surveys and our firm-level settlement data we estimate that about $52 \%$ of the firms in our sample among those that agreed to settle had to pay some out-of-pocket settlement costs.

There are several empirical challenges associated with estimating a relation between litigation risk and corporate policy. The first is that of an omitted variable bias. It is possible that an unobservable factor may be causing both the initiation of a class action lawsuit and changes in firm financial policy. A second issue is that of a possible simultaneity bias or reverse causality. Firms may hold higher cash balances because of their exposure to litigation risk, but firms with higher cash balances may be more likely targets of litigation. As such, we investigate the impact of litigation risk on corporate cash holdings in both the cross-section and over time using a variety of approaches. To address the potential for omitted variables bias, we assess the effect of changes in litigation risk on changes in cash holdings by analyzing the spillover effects of litigation on industry peer firms not involved in a litigation. This identification strategy is motivated by the findings of Gande and Lewis (2009) that firm share prices drop significantly when a peer firm is brought into a class action lawsuit. To deal with potential simultaneity bias, we employ a simultaneous equations framework, similar to the analysis of Lowry and Shu (2002) and Field, Lowry, and Shu (2005). Regardless of the approach we use to estimate litigation risk, our results consistently show a significant positive relation between litigation risk and cash holdings. After accounting for endogeneity, our results show that firms preemptively accumulate cash before possible lawsuits rather than plaintiffs targeting firms with high pre-litigation levels of cash.

In addition to class action securities lawsuits, firms are exposed to other legal risks, such as copyright infringement, product liability, and antitrust lawsuits. As with other papers examining litigation risk, we choose to focus on securities class action lawsuits. This choice is motivated by several reasons. First, class action securities fraud litigations are brought under the Securities Acts of 1933 and 1934. As such, all publicly traded firms are susceptible to this particular type of lawsuit. Second, detailed information related to the class action lawsuits is publicly available for a longer period than other types of lawsuits, and provides us with a large observable sample of litigation events. Finally, class action securities litigation is of 
interest because the average settlement or penalty amounts tend to be quite large and therefore represents a significant source of loss from the firm's perspective. In our sample of lawsuits, the average settlement amount is $\$ 56.4$ million, which corresponds to more than the level of cash holdings of the sued firms that settle. Moreover, the statistical distribution of settlement amounts is characterized by considerable positive skewness. A few settlements surpass the $\$ 1$ billion mark, and the largest settlement in our sample amounts to $\$ 3.2$ billion. In addition to the direct costs of litigation represented by settlement costs and attorneys fees, sued firms face several indirect costs (Engelmann and Cornell (1988)). Even though indirect costs are difficult to measure, they are significant in most cases. When a firm becomes a defendant in a lawsuit, the cost of implicit and explicit contracts rises. Major lawsuits can also damage the defendant's reputation and can negatively affect its relationship with suppliers and customers (Engelmann and Cornell (1988)). One potential concern with our sample of events is that securities litigation may be more sensitive to changes in firm performance compared to other types of litigation. While we do control for changes in performance in our analysis, we also investigate other litigations that are not related to securities law from the Audit Analytics litigation database. The results from the sample of non-securities litigation events are similar to our main results, suggesting that the effects of litigation risk are not limited to class action securities litigation.

We start our empirical investigation by examining whether changes in litigation risk lead to changes in cash holdings for firms directly involved in securities litigation. We do so by examining the impact of actual class action lawsuits filed on US firms between 1996 and 2006. We find that, controlling for changing firm characteristics, cash holdings of these firms increase by an average of $15.5 \%$ relative to pre-litigation levels. The results are robust to different specifications and the inclusion of firm and year fixed effects.

One important concern related to the link between cash holdings and litigation risk is the potential endogeneity between the choice of how much cash to hold and the decision of shareholders to file litigation. To identify the causal effects of litigation risk, we examine the spillover effects of class action litigation on peer firms. Gande and Lewis (2009) demonstrate that the share prices of firms that are not brought into a legal dispute adjust downward significantly on the announcement of a lawsuit filing of a firm in the same industry. They also show that litigation concentration in a particular in industry is a strong predictor of actual litigation 
events. Thus, we treat litigation events on peer firms as an exogenous source of variation in litigation risk for firms in the same industry. We find that peer firms increase their cash holdings significantly when industry peers are involved in litigation. Specifically, the conditional mean cash-to-assets ratio for peer firms increases by $10.2 \%$ relative to pre-litigation levels following a litigation event in their industry.

In addition to the spillover effects analysis, we also deal with the potential simultaneity problem by estimating a system of simultaneous equations that allows us to decompose the impact of litigation risk on cash holdings (the precautionary savings motive) and the impact of cash holdings on litigation risk (the enticement effect). The approach we employ is similar to that adopted by Lowry and Shu (2002), who examine the impact of litigation risk on IPO underpricing. The results of this system of simultaneous equations dispel concerns of reverse causality. The evidence from the simultaneous equations suggests that firms accumulate cash in anticipation of a possible lawsuit. The estimates do not support the conjecture of firms with larger amounts of cash being more exposed to predatory class action lawsuits.

We then examine corporate investment policy around litigation events. We find a significant reduction in capital expenditures for firms involved in litigation, controlling for Tobin's $Q$ and cash flow. We also find evidence of litigation spillover effects in corporate investment. Specifically, we find that firms reduce their capital expenditures when they see some of their competitors being sued. The spillover effect is economically and statistically significant, though smaller in magnitude compared to the firms that are directly involved in the lawsuit.

Having established that firms increase their cash holdings in the face of increased litigation risk, a natural question is whether this accumulation of cash has an impact on firm value. Given that a successful lawsuit from the plaintiff's perspective will lead to a net payout of cash to the litigation claimants that in many instances are not current shareholders of the firm, we expect that the value of the marginal accumulated dollar of cash will be lower for firms exposed to litigation risk. Using the methodology of Faulkender and Wang (2006), we find that the risk of litigation decreases a firm's marginal value of cash. Our finding that the value of an additional dollar of cash is significantly lower for firms exposed to litigation risk is also consistent with Gormley and Matsa (2009), who argue that shareholders of firms exposed to 
litigation risk would prefer to receive higher payouts because excess cash might potentially increase damage awards.

Overall, our results on the relation between litigation risk and cash holdings are robust to different proxies of litigation risk, endogeneity concerns, an extensive set of firm characteristics that previous studies have shown to be related to cash holdings levels (e.g., Kim, Mauer ,and Sherman (1998); Opler, Pinkowitz, Stulz, and Williamson (1999); Mikkelson and Partch (2003)), corporate governance characteristics (Harford, Mansi, and Maxwell (2008), Dittmar and Mahrt-Smith (2007)), unionization rates (Klasa, Maxwell, Ortiz-Molina (2009)), the inclusion of other risk proxies, different empirical specifications, different measures of cash holdings, and concerns about possible spurious effects due to temporal trends. Our results also hold when we include all types of corporate lawsuits in our analysis.

Our paper makes two primary contributions. First, we contribute to the literature on the effects of securities litigation risk on firm behavior and corporate disclosure and financial decisions. Litigation risk of various types is related to IPO underpricing (Lowry and Shu (2002)), financial reporting and accounting disclosure (Skinner (1994, 1997), Field, Lowry, and Shu (2005)), leverage (Crane (2011)), institutional monitoring (Cheng et al. (2010)), MD\&A disclosures(Brown and Tucker(2011)), audit fees(Seetharaman, Gul, and Lynn (2002)), and executive pay (Peng and Roell (2007)). Gormley and Matsa (2009) investigate firm responses to liability risk arising from its workers' exposure to newly identified carcinogens, finding that firms respond to that type of litigation risk by engaging in diversifying acquisitions. We extend this stream of research by investigating the link between securities litigation risk, cash holdings, and corporate investment policy, providing another avenue whereby legal institutions affect corporate behavior. Second, we identify a new determinant of cash holdings and provide evidence that litigation risk has a significant effect on corporate liquidity and investment policy, supporting the view that the precautionary savings motive is particularly important. This paper identifies a clear channel whereby precautionary savings operates and contributes to cash holdings and depress investments. Our results also offer an insight into how firms manage risk in an integrated framework by both entering into insurance contracts and adjusting the firm's financial structure to hedge litigation risk. 
The remainder of this paper proceeds as follows. Section \summarizes and describes our sample of firms and litigation events. Section [I] presents our primary empirical results. Section III discusses our robustness tests. Finally, Section IV offers a summary and conclusions.

\section{Data}

\section{A. Sample}

Our initial sample consists of the entire population of Compustat firms from 1996 to 2006 with no missing data for the main variables used in the analysis. We then match our sample with the CRSP database and exclude firms that CRSP does not cover. After this match our sample contains 84,078 firm-year observations. We then match this sample with Execucomp and First Call to obtain variables required by some of our multivariate tests. After this match our sample consists of 13,589 observations. We then identify a sample of firms subject to class action lawsuits by collecting litigation data from the Securities Class Action Clearinghouse website (http://securities.stanford.edu/) from 1996 to 2006. We collect information about lawsuit filing dates, beginning and ending of each class period, type of resolution and settlement amounts when available. We identify 1,397 sample firms as being involved in security class action lawsuits during our sample period. Definitions for the variables used in this study are included in the Appendix.

We also collect information about corporate litigations other than security class action lawsuits from the Audit Analytics Litigation database. The data coverage begins in 2000 and reports information on lawsuits for U.S. publicly-traded firms. Audit Analytics collects information from corporate disclosures, corporate newswires, and from legal disclosures, registrations and legal opinions filed with the SEC. Audit Analytics reports details related to the specific litigation, including the type of lawsuits, the original date of filing, and if available, the settlement amount. Our sample of non-security lawsuits obtained from Audit Analytics spans from 2000 to 2006 and consists of 4,396 firm-year observations (firms that were sued at least once in a given fiscal year). The most common types of corporate lawsuits are product liability, copyright, patent, antitrust, and trade regulation lawsuits. 


\section{B. Matching procedure}

The simultaneous equation analysis we discuss in Section $\amalg$ is confined to the analysis of those firms that are directly involved in a class action lawsuits during the sample period along with a matching sample of non-litigation firms matched on past profitability, market-to-book and industry. The matching sample consists of 1,397 litigation firms and 1,397 control firms for a total of 2,794 firm observations. To match our sample of firms involved in a class action lawsuit with comparable firms not involved in a litigation we use the Lie (2001) modification of the Barber and Lyon (1996) method in which companies are matched by industry affiliation, profitability, change in profitability and market-to-book 3 . We select matching firms that have the same industry classification of the sample firms and are similar in level of operating performance in the year preceding the start of the lawsuit (year -1), change in performance from year -2 to year -1 , and market-to-book ratio in year -1. In the first step of our matching procedure we identify firms (a) with the same two-digit SIC code of the sample firms, (b) with a level of operating performance between 80 percent and 120 percent of the sample firm's level in year -1, (c) with a change in operating performance between 80 and 120 percent of the sample firm's change between year -2 and year -1 , and (d) with a market-to-book ratio between 80 and 120 percent of the sample firm's ratio in year -1 .

If more than one firm meets the matching criteria for a single sample firm, we choose the one that minimize the following metric:

$$
\left|O P_{S}-O P_{M}\right|+\left|\Delta O P_{S}-\Delta O P_{M}\right|+\left|M B_{S}-M B_{M}\right|(1),
$$

where $O P_{S}$ and $O P_{M}$ are the level operating performance in year -1 for the sample and matching firm, $\triangle O P_{S}$ and $\triangle O P_{M}$ are the changes in operating performance between year -2 and year -1, and $M B_{S}$ and $M B_{M}$ are the market-to-book ratios in year -1. If we cannot find any firm satisfying condition (b), we look for firms with a level of operating performance within \pm 0.01 of the level of the sample firm. We apply the same strategy for the change in operating performance or the market-to-book ratio if we do not find any firm satisfying condition (c)

\footnotetext{
${ }^{3}$ An alternative match by industry, market-to-book, and size instead of profitability generates a sample that produces comparable regression results to the one presented in the paper.
} 
or condition (d) 4 . If we do not find any firm that meets these criteria we repeat the process looking at firms with the same 1-digit SIC code. If this search is unsuccessful, we match the firm independently from the SIC code. If we still do not find a valid match, we select the firm that minimizes formula (1) independently from our filters.

\section{Descriptive Statistics}

Table【presents the distribution of litigation firms by year and industry. The year with the largest amount of lawsuit filings in our sample is 2001. Out of the 319 lawsuits initiated that year, 199 (68.8\%) involve firms in the communications, computers and electronics industry $($ SIC $=3570-3579,3600-3699,4800-4899,7370-7379)$. The very large number of lawsuits for this industry in 2001 is likely due to the burst of the internet bubble that characterized the US stock market during that period.

Table Ip presents descriptive statistics on the resolution of the lawsuits involving our sample firms. Of the 1,128 (81\%) cases that reached a resolution by the end of 2009, the majority (613) settled. Panel A of Table I shows that when the plaintiffs receive compensation, it is always through settlement. The descriptive statistics of settlement amounts presented in Panel B of Table In show that in many circumstances the monetary awards negotiated through settlements are considerably high. The mean settlement award in our sample is \$56.4 million - an amount larger than the average level of cash held by the sued firm at the year of filing. Even when we include dismissed and withdrawn cases in the computation of the settlement statistics by assigning to those cases an award of $\$ 0$, the mean settlement award to cash holdings is $59.6 \%$. The largest settlement award amounts to $\$ 3.2$ billion. These summary statistics demonstrate that these settlement amounts are by no means trivial. In addition to explicit settlement costs, firms face other direct costs (e.g., attorneys fees), and several indirect costs described earlier. Effectively, the total amount of litigation costs is higher than the settlement costs presented in Table

\footnotetext{
${ }^{4}$ For market-to-book we look for firms with a level of MB within \pm 0.1 of the level of the sample firm.
} 


\section{Empirical Results}

\section{A. Litigation Risk and Cash Holdings}

We first examine the impact of litigation events on cash holdings in a univariate setting. We then explore the relationship between litigation and cash holdings by employing various multivariate analyses. We begin by analyzing the effect of litigation events on firms that are directly involved in securities litigation. While these results are suggestive of an effect, they are subject to possible omitted variables and simultaneity bias. To better assess the causal link between changes in litigation risk and cash holdings, we examine the effect of a litigation event for a particular firm on the cash holdings of peer firms that are not involved in litigation themselves. Since higher cash holdings may increase the probability of a litigation event in the first place, we then jointly estimate the probability of being brought into litigation and the effect of litigation on the firm's cash holdings. We also investigate the value implications of increased cash holdings brought on by changes in litigation risk. We then analyze the effect of litigation risk on corporate investments.

\section{B. Univariate Analysis}

Table III reports summary statistics for the cash holdings of US firms involved in litigations over the period 1996 to 2006. We report summary statistics in event time, where year zero represents the year of the litigation filing. We calculate means and quartiles of the cash distribution for the two years prior and the two years following the litigation event. The mean cash to total assets ratio in the year prior to the litigation filing is 0.223 . Cash holdings jump significantly in the year of the litigation, rising $17.5 \%$ relative to the pre-litigation level to 0.268. The increase in cash holdings appears to be persistent, remaining higher at nearly $25 \%$ of total assets two years after the filing. Panel B confirms that this increase is statistically significant for both the year of the litigation and the two-year period immediately following the lawsuit. The mean difference between the litigation year and the two prior years is 0.039 with a $\mathrm{t}$-statistic of 3.545. The mean difference between the post-litigation period (years 1 and 2) and 
the pre-litigation period (years -2 and -1 ) is also statistically significant, with post-litigation holdings averaging 0.025 higher than pre-litigation years.

To check that the mean increase is not driven by a few outliers, we also summarize changes in the distribution of cash holdings in event time. Panel A reports the first quartile, median, and third quartile of the cash holdings distribution for firms involved in litigation. The entire distribution of cash holdings for the sample firms shifts upwards. The first quartile increases from 0.029 to 0.046 in the litigation year, while the median and third quartile increase from 0.130 to 0.185 and 0.369 to 0.490 , respectively.

The firm's involved in litigation in our sample have slightly higher cash holdings even before the litigation event. Two years before litigation, firms in the sample have a mean cash-to-assets ratio of 0.224 , compared with 0.191 for the overall Compustat sample. Firms are possibly anticipating the incidence of a lawsuit and begin accumulating additional cash. Alternatively, firms with higher cash holdings might be more likely to be targeted for litigation in the first place. In our multivariate analysis we revisit this possibility by investigating this possible reverse causality between cash holdings and litigation risk.

\section{Effects of Litigation on the Cash Holdings of Sued Firms}

The univariate results suggest that firms involved in litigation increase their cash holdings. We now turn to a multivariate approach to control for changing firm characteristics and time trends that may also affect changes in cash holdings. We estimate several specifications of cash regressions in which we include a series of event dummy variables to capture the changes in cash holdings following a litigation event. The specification of the cash holdings regression is similar to that of Opler et. al (1999) and Bates, Kahle, and Stulz (2009), who identify potential determinants of cash holdings, both in the cross-section and over time. The dependent variable in the regressions is defined as cash and short-term investments scaled by net-of-cash total assets. As control variables, we include firm size, leverage, cash flow, net working capital, dividend paying status, market-to-book ratio, capital expenditures, acquisition expenditures, R\&D to sales ratio, net debt and equity issuance, and cash flow volatility. The specific definitions of these variables are included in the appendix. We include four litigation event dummy 
variables, $L_{k}$, for $k=0,1,2,3$ where year zero is the litigation initiation year. The timing of the dummy variables is set to capture the duration of actual litigation events. Klausner and Hegland (2010) find that the average time from class action filing to settlement is close to two years. We also include firm, industry, and year fixed effects in various specifications.

Table IV reports the estimates from the cash holdings regressions. Standard errors are clustered at the firm level in all specifications. The first specification is estimated via ordinary least squares without industry and time effects. The second specification adds time effects in the form of calendar year dummies. The third and fourth specifications include industry fixed effects, with the fourth specification including both industry and year dummies. The magnitude and signs of the coefficients of the control variables are consistent with previous research. The coefficients on the litigation event dummies are positive and statistically significant across all specifications, suggesting that firms increase their cash holdings significantly following a litigation event. Cash holdings increase following the litigation and stay high for the two years following the litigation and then start to drop in the third year, consistent with the average duration of litigation events reported by Klausner and Hegland (2010). The fixed-effects estimates suggest that firms increase their cash holdings above their pre-litigation levels by almost $4.5 \%$ of total assets. In economic terms, this translates into a relative increase of about $15.3 \%$ relative to pre-litigation levels. To control for time-variant unobservable variation, the fifth specification includes both firm and year fixed effects. This specification captures the within-firm variation in cash holdings around a litigation event. The coefficient of the litigation dummy is positive and statistically significant, suggesting that firms change their cash holdings in response to litigation.

Bates, Kahle and Stulz (2009) indicate that cash holdings in the United States have a significant temporal trend. They find in their sample that average cash holdings increase by $129 \%$ between 1980 and 2004. While we control for various measures of time-varying firm risk and calendar year dummies, there is still some concern that our results might be coming from nonlinear temporal trends in the data. To address this concern, we re-estimate the cash holdings regressions over the sample period using random 'placebo' dummy variables. To do this, we randomly select firm-year observations each year to serve as a random event. We sample with replacement from the overall Compustat sample each year. The sample size is selected such that the relative frequency of random events each year matches the relative frequency of actual 
litigation events as reported in Table \. For each firm-year randomly selected, we create the set of dummy variables described above where year zero is the year of selection. After the random selection, we end up with a series of dummy variables that looks like the litigation event variables in the previous regressions, except that the timing is randomly allocated across the panel. Thus, if a temporal trend were driving the results in the earlier specifications, we would expect a significantly positive coefficient on the random placebo variable. Specification (6) of Table IV reports the estimates of this random placebo test. All of the estimates on the control variables are similar as in the other specifications. The coefficients on the placebo dummy variables are insignificant, suggesting that the effects in the other regressions are systematically related to litigation events and not to temporal trends in the sample.

While consistent with the hypothesis that the risk of securities litigation leads firms to hold more cash, the results in Table IV may be driven by an omitted variable that drives both changes in cash and a litigation event. In the next section, we address this concern by employing industry spillover effects to identify a cleaner link between litigation risk and changes in cash holdings.

\section{Spillover Effects}

The fundamental question we wish to address in this paper is whether litigation risk leads firms to hold more cash. While we have demonstrated robust evidence consistent with this hypothesis, establishing a causal link is challenging. Litigation risk is inherently unobservable and difficult to measure. In order to assess the causal link between litigation risk and cash holdings, we examine the spillover effects on other firms that are not actually involved in litigation. The existence of spillover effects around litigation events suggest that firms update their subjective probability of being brought into litigation when a peer firm has a case filed against it. Gande and Lewis (2009) find strong evidence of spillover effects in litigation. They find that lawsuits in a given industry signal an increased possibility that other firms in the same industry may be sued as well. In particular, they find that peer firms have negative stock price reactions to the announcement of litigation events for peer firms. In addition, Kim and Skinner (2012) find that industry membership is not a particularly good predictor of firm-level litigation events unless the specification used to predict events also contains firm- 
specific variables. It is reasonable then to assume that an actual lawsuit within an industry is a good proxy for changes in litigation risk for other firms in the same industry. Employing the spillover proxy addresses the concerns about potential endogeneity as it is unlikely that the characteristics of a firm not involved in litigation are driving the lawsuits of other firms.

We first estimate spillover effects in the panel of firms in our sample. We set the industry litigation dummy variable to one for a given firm year if another firm in the same four-digit SIC industry has had a class action lawsuit filed against it in the same year. Firms that are actually involved in litigation events are dropped from the sample 5 We then estimate the cash holdings regression including firm and year fixed effects. The results are reported in the first column of Table $\nabla$. The coefficient on the industry litigation dummy variable is positive and statistically significant, suggesting that exogenous changes in litigation risk exposure lead to higher cash holdings.

We also estimate the time-series effect of litigation on peer firms by constructing industrylevel observations based on firms that have not yet been involved in a litigation event. For every 4-digit SIC industry each year, we include all firms that have not had any lawsuits filed against them prior to that year. If at any time a firm in an industry becomes involved in litigation, that firm is removed from the sample and we set an event dummy variable equal to one for that industry. We use this dummy variable to measure the impact of the litigation on the other, non-sued firms in the industry. The industry characteristics (cash holdings, leverage, etc.) are measured in two ways. In the first approach, we equal-weight each firm in the industry, so that a particular characteristic is the average of the firm characteristics of all firms in that particular industry in a given year. In the second approach, we value-weight the observations by summing up the numerators of the firm ratios and dividing them by the sum of the denominators. For example, the industry cash holdings variable for industry $k$ in year $t$ would be

$$
\operatorname{Cash}_{k t}=\frac{\sum_{i=1}^{N_{k}} \operatorname{Cash}_{i t}}{\sum_{i=1}^{N_{k}} \operatorname{Assets}_{i t}},
$$

\footnotetext{
${ }^{5}$ We have repeated the analysis with the sued firms included in the regression and the results are similar. The results are available upon request.
} 
where $N_{k}$ is the number of firms in industry $k$. We also control for industry performance measured by industry-level stock returns, cash flow, and cash flow volatility to address the possibility that poor industry performance is driving both the litigation events and the observed spillover effects.

Table $\mathrm{V}$ reports the results of the industry cash regressions. Column 2 reports the results from the equal-weighted industry observations, while column 3 reports the results for the value-weighted observations. The unconditional mean cash-to-assets ratio for the industry portfolios is 0.130 for the equal-weighted observations and 0.100 for the value-weighted observations. Table $\mathrm{V}$ demonstrates that litigation has an effect on the cash holdings of peer firms in the same industry. Across all specifications, the coefficient on the industry litigation dummy is positive and statistically significant. The results are also economically significant. The estimates imply that industry cash holdings for the firms that are not involved in the litigation increases by $10.2 \%$ relative to the unconditional average in the equal-weighted case and a $15 \%$ increase in the value-weighted case, suggesting that an exogenous change in the probability of a future lawsuit leads firms to increase their cash holdings.

One potential concern with the industry-level regressions is that a large proportion of litigations in our sample were against technology firms just following the crash of the internet/technology bubble in 2001. It is possible that the technology firms that survived the crash increased their cash holdings as a consequence of bad performance and the same time were brought into litigation. To address this concern, we estimate the industry-level regressions with the firms in the communications, computers and electronics industries ( $\mathrm{SIC}=3570-3579$, 3600-3699, 4800-4899, 7370-7379) omitted from the sample. The results are reported in the last column of Table V. The magnitude and size of the coefficient on the industry litigation event dummy is similar to that of the full sample, suggesting that the results are not driven by the dynamics of tech firms around the crash of the internet bubble.

\section{E. Joint Estimation of Cash Holdings and Litigation Risk}

The results to this point suggest that firms tend to accumulate excess cash as a form of insurance against future possible litigations. However, as mentioned earlier, higher levels 
of cash holdings might also increase the probability of class action lawsuits. We capture the interaction between these two effects and control for the possible endogenous relation between litigation risk and cash holdings by adopting the approach used by Lowry and Shu(2002) and Field, Lowry, and Shu (2005). For this analysis we use the Lowry and Shu(2002) ex ante proxy for litigation risk by assigning the value of one to a litigation risk dummy for the firms that are involved in a litigation in the following year, and zero otherwise.

We use the following system of equations:

$$
\begin{aligned}
& \text { Insurance Effect : Cash Ratio }=\gamma_{1} \text { Litigation }+\theta_{1} X+\beta_{1} X_{1}+\varepsilon_{1}, \\
& \text { Enticement Effect : Litigation }=\gamma_{2} \text { Cash Ratio }+\theta_{2} X+\beta_{2} X_{2}+\varepsilon_{2},
\end{aligned}
$$

where Cash Ratio is the ratio of cash and marketable securities to the book value of total assets for firm $i$; Litigation is the litigation risk for firm $i$, as described above; $X$ is a vector of control variables, exogenous firm characteristics that are common to both equations because potentially related both to the cash ratio and to litigation risk; $X_{1}$ is the identifying variable of the first equation, an exogenous firm characteristic that is uniquely related to the cash ratio, but not to litigation risk; and $X_{2}$ is the identifying variable of the second equation, an exogenous variable that is directly related to the probability of a lawsuit but not to the cash ratio.

As identifying variable $X_{1}$ we use firm leverage. The negative significant relation between leverage and the cash ratio is well established in the finance literature (e.g., Opler et al. (1999) and Bates, Kahle, and Stulz (2007)). However studies of litigation risk determinants do not find a significant relation between leverage and litigation risk (e.g., Cao and Narayanamoorthy (2006)). As identifying variable $X_{2}$ we use stock turnover. Stock turnover is related to plaintiffs' incentives to initiate lawsuits because settlement amounts are generally increasing in the number of shares traded at the allegedly misleading prices (Lowry and Shu (2002)). However, stock turnover is not related to the cash ratio.

Our simultaneous equation analysis uses an indicator variable equal to 1 when a firm is actually involved in a lawsuit in the following year. The litigation firms are matched with control firms using the matching procedure described in Section I The simultaneous equation model has both a continuous and a dichotomous dependent variable. In order to estimate the 
model and correctly determine the standard errors we apply the two-stage Maddala (1983) method as in Lowry and Shu (2002). In the first stage, we fit the two models with an OLS and probit regression respectively, using all the exogenous variables. In the second stage, we replace the original endogenous variables (cash ratio and litigation) with their respective fitted values. In this system of equations the exogenous variables refer to the fiscal year preceding the litigation filing date. Therefore, the regressions generate ex ante estimates of cash holdings and litigation risk.

Table VI presents the results of the second-stage regressions in which the dependent variables are the cash ratio and the litigation indicator variables respectively 6 . The table presents three different specifications. The first specification does not contain unionization rates and governance variables, the second specification contains the unionization rate variable, and the third specification contains the governance index and managerial ownership variables.

In all specifications the litigation instrument (fitted value from the first stage) is significantly related to the cash ratio, consistent with firms accumulating cash preceding the filing of a lawsuit. The cash ratio instrument (fitted value from the first stage) is however not significantly related to litigation risk. Thus, our estimation results do not support the conjecture that firms with larger amounts of cash are more exposed to predatory class action lawsuits. The majority of the coefficients of the other variables in the first specification are consistent with previous literature on cash holdings and litigation risk, suggesting that the significant relation between litigation risk and cash holdings is not due to the correlation between litigation risk and other firm characteristics such as firm size or amount of dividend payouts.

In the second specification we control for the potential effect of industry unionization rates on the level of cash holding 7 . While our main results persist, the unionization rate variable in the cash second-stage regression is not significant. Our results, however, are not at odds with Klasa, Maxwell, and Ortiz-Molina (2009) because our sample is quite different from theirs. Our sample is not restricted to manufacturing firms and contains only firms involved in a class

\footnotetext{
${ }^{6}$ The results of the first-stage regressions are available upon request.

${ }^{7}$ The industry unionization rate data that is publicly available at www.unionstats.com is organized by Census Industry Classification (CIC) industries. Since some general SIC four-digit industries ending with 00 do not correspond to any specific CIC industry, about $5 \%$ of our observations have missing unionization rates when we merge our Compustat data with unionization data. In order to avoid losing these observations in our regressions we equal missing unionization rates to 0 and create a "missing unionization" indicator variable equal to 1 when unionization rates are missing, and 0 otherwise.
} 
action lawsuit along with their matches. The difference between our sample and those in Dittmar and Mahrt-Smith (2007) and Harford, Mansi, and Maxwell (2008) might also explain the lack of significance of the G-Index variable in our third specification.

\section{F. Litigation and Corporate Investments}

The results above demonstrate that firms increase their cash holdings in response to changes in exposure to litigation risk. An important question that arises is whether this behavior has any effect on real investment. That is, do firms forgo investment in order to save cash due to the lawsuit? To examine this possibility, we estimate the investment regression

$$
I_{i t}=\alpha_{i}+\beta_{1} \text { Litigation }_{i t}+\beta_{2} Q_{i, t-1}+\beta_{3} C F_{i, t-1}+\gamma_{t}+\varepsilon_{i t},
$$

where $I_{i t}$ is capital expenditures scaled by beginning-of-year net property, plant and equipment, $Q_{i, t-1}$ is beginning-of-year Tobin's $Q$, and $C F_{i, t-1}$ is the beginning-of-year cash flow rate, and Litigation ${ }_{i t}$ is set equal to one if the firm is involved in a class action lawsuit in year $t$.

The first two columns of Table VII report the results where the litigation dummy is constructed based on the firms actually involved in the litigation. We see that for both specifications, capital expenditures decrease significantly during the class action filing year, consistent with the view that firms are forgoing investment to accumulate cash. The third column considers litigation spillover effects on corporate investment. Here, we define the litigation dummy based on the litigation events of peer firms in the same four-digit SIC industry. Thus, the dummy is set to one for firm $i$ if a firm in the same industry is involved in a class action lawsuit in year $t$. The results provide evidence of spillover effects in corporate investment. Firms that are not involved in litigation reduce capital expenditures and save cash when peer firms are sued. The magnitude is smaller than for the sued firms, but still economically significant. The coefficient on the litigation dummy in column three implies that firms reduce their investment rates on average by about $4.6 \%$ compared to years when no firms in an industry are in the litigation process. 
One concern related to the investment results is the impact of measurement error in Tobin's $Q$ on our estimates. Since the actual Tobin's $Q$ is unobservable, our proxy may be measured with error. If the measurement error in our proxy for Tobin's $Q$ is correlated with the litigation event dummy variable, then the coefficient of interest may be biased. To address this concern, we employ the reverse regression bounds approach of Erickson and Whited (2005) in order to ensure the robustness of the sign of our estimate. We find that that our estimated treatment effect is robust to this concern because of a relatively low correlation with our proxy for $Q^{8}$. The low correlation implies that any measurement error contained in our litigation event variable is likely to lead to the usual attenuation bias of the OLS coefficient, suggesting that if anything, our estimate of the effect of litigation on investment is conservative.

\section{G. The Effect of Litigation Risk on the Market Valuation of Cash Hold- ings}

The evidence offered by our tests thus far presents a consistent picture. Firms that perceive being significantly exposed to litigation risk tend to accumulate cash in excess over what is predicted by the determinants established previously by the literature. An important question is how the market values these changes in cash holdings. In this section we investigate to what extent cash that is put aside preemptively to cope with the anticipated cost of litigation contributes to firm value. A large portion of the settlement paid by the defendant firm is allocated to plaintiff shareholders that are no longer shareholders of the firm at the time of the settlement. Moreover, legal fees sustained by the defendant firm are often significant. We expect, therefore, that the changes in cash held by firms at risk of litigation contribute less to shareholder value than cash of firms with low or no risk of litigation.

We investigate this issue by applying the method introduced by Faulkender and Wang (2006). We present the results of our analysis on the valuation of cash holdings in Table VIII. We construct an ex ante measure of exposure to litigation risk as the predicted probability from a probit model similar to Kim and Skinner (2012)9. With the exception of the litigation

\footnotetext{
${ }^{8}$ Results available upon request.

${ }^{9}$ The estimation details and estimates are reported in the Internet Appendix.
} 
risk variable 10 and the unionization rate variables, we construct all the other variables as in Faulkender and Wang (2006). We measure all variables for the fiscal year preceding the litigation filing. The dependent variable is the firm's excess stock return calculated as the firm's annual stock return minus the annual stock return of the matched Fama and French $5 \times 5$ size and book-to-market portfolio. With the exception of the litigation variable, leverage, and the unionization variables, we scale all other independent variables by the lagged market value of equity.

The results of all regressions presented in Table VIII show that, consistent with Faulkender and Wang (2006) and Pinkowitz and Williamson (2007), the coefficient of the annual change in cash holdings is positive and significant. The litigation risk variable is negative and significant suggesting that, everything else constant, the stock market values significantly less firms exposed to litigation risk. The coefficient of the interaction between the change in cash holdings and the litigation risk variable is negative and significant, indicating that the marginal value of an additional dollar of cash is lower for firms exposed to litigation risk. These findings are consistent with the plaintiff law firms and former shareholders receiving a significant portion of the cash disbursed by the company. Our result persists also when controlling for the potential effect of the degree of industry unionization on the value of cash holdings as in Klasa, Maxwell, and Ortiz-Molina (2009), and the Gompers, Ishii, and Metrick (2003) governance index as in Dittmar and Mahrt-Smith (2007).

In order to appreciate the economic significance of the litigation risk on the value of cash, we calculate the marginal value of a dollar of cash for the average sample firm using the mean values of the independent variables that interact with the change in cash and their coefficients in the first specification. We use the mean values of cash holdings divided by market value of equity and market leverage of $21.5 \%$ and $15.2 \%$, respectively. The marginal value of a dollar of cash for a company with an average predicted probability of litigation (3.6\%) is therefore $\$ 0.93=1.246-1.146 * 3.6 \%-0.084 * 21.5 \%-1.667 * 15.2 \%$. This value is almost identical to the marginal value of a dollar of cash for the average firm of $\$ 0.94$ obtained by Faulkender and Wang (2006). The marginal value of a dollar of cash for a company with a predicted probability of litigation one standard deviation above the mean $(9.6 \%)$ is $\$ 0.86$. The marginal

\footnotetext{
${ }^{10}$ We have used other measures of litigation risk, including the litigation event dummy variable employed in the earlier analysis and alternative probit models described in the robustness section
} 
value of a dollar of cash for a company with a predicted probability of litigation equal to zero (one standard deviation below the mean would be a negative number) is instead $\$ 0.97$, that is $\$ 0.11$ higher. These results show that the contribution of litigation risk to the firms' value of cash is economically significant. Overall, the results presented in Table VIII show that the negative effect of litigation risk on the incremental value of cash holdings is both statistically and economically significant.

\section{Robustness Checks}

In additional robustness tests, we demonstrate that various ex ante measures of litigation risk are positively and significantly related to cash holdings in the cross-section of US firms, controlling for all other factors that are known to be correlated with cash. Similar to Kim and Skinner (2012), we construct ex ante measures of litigation risk by obtaining predicted probabilities from a series of probit regressions that attempt to explain the probability that a firm is sued in a given year. The economic effects of litigation risk are significant and quite large. We find that a one-standard deviation increase in the ex-ante measures of litigation risk yield expected increases in the conditional mean cash/assets ratio ranging from $5.9 \%$ to $6.5 \%$, depending on the specific measure and model specification 11.

In this section, we conduct various robustness tests related to the cash holdings results presented above. One possible concern is related to using the ratio of cash to net-of-cash total assets as our measure of cash holdings. Possible changes in the level of assets before a lawsuit could significantly change the value of this variable and generate spurious results. If, for instance, the goodwill impairment following an unsuccessful merger triggered a class action lawsuit, the cash ratio would be higher pre-litigation due to a decline in assets (the denominator) instead of an increase in cash (the numerator). To address this concern, we replicate all our multivariate tests replacing the cash ratio with the natural logarithm of cash and short-term securities to verify that our results are driven by cash levels and not assets levels. The coefficient on the litigation dummy is large, positive, and statistically significant, suggesting that our results are driven by changes in cash levels and not by changes in assets.

\footnotetext{
${ }^{11}$ Estimation details and results for all of the robustness tests listed in this section are included in the Internet Appendix
} 
Even though class action security lawsuits are the most common type of litigation faced by U.S. corporations, there exist many other types of lawsuits. As reported in the data section, we collect information about corporate litigations other than security class action lawsuits from the Audit Analytics Litigation database. Our sample of non-security lawsuits obtained from Audit Analytics spans the time period from 2000 to 2006. The most common types of other corporate lawsuits are product liability, copyright and patent, and antitrust and trade regulation litigations. These lawsuits are less likely to be triggered by a decline in stock price performance than are security lawsuits. Therefore, expanding the sample to all lawsuits allows us to verify that our results are not driven by a possible correlation between a general shortfall risk and litigation risk 12 . We find a strong, positive relationship between cash holdings and measures of litigation risk based on these other types of litigation events. The findings suggest that other types of litigation, not just securities law cases, have a significant effect on corporate liquidity policy.

\section{Conclusions}

In this study we link a major external source of corporate risk, securities class action litigation risk, with two of the main corporate financial decisions that executives have to make, the amount of cash to hold on the balance sheet and the level of corporate investments to sustain firm's growth. We find that the risk of securities litigation significantly affects the amount of cash firms choose to hold. Firms at risk of being sued tend to hold significant larger amounts of cash even after controlling for a comprehensive array of cash determinants and possible time effects. We also show that firms pre-emptively accumulate cash before possible lawsuits rather than plaintiffs targeting firms with high levels of cash. The impact of litigation risk on cash holdings is not limited to firms that are actually sued. We find strong evidence of spillover effects within industries, suggesting that our results are not due to an omitted variables bias. That is, when a firm is brought into a class action lawsuit under the Securities Acts, peer firms in the same industry respond by increasing their holdings as they revise their perceived exposure to litigation risk upwards.

\footnotetext{
${ }^{12}$ This is, however, a minor concern because in our main regressions we control for systematic and idiosyncratic risk.
} 
We find that litigation risk affects corporate investment decisions. Our results suggest that firms forgo capital expenditures to save cash in response to increases in litigation risk exposure. This finding suggests that the legal protection available to firms stakeholders can have the unintended consequence of depressing the level of corporate investments. We also provide evidence on the impact of litigation risk on the marginal value of cash. A dollar of cash is worth less for firms at risk of litigation, likely a reflection of the multiplicity of recipients of class action lawsuit settlements. Even though cash provides insurance against possible lawsuit settlements costs, because part of the cash disbursed by the defendant firm goes to the plaintiff law firms and stakeholders that do not currently own shares of the defendant companies, shareholders appear to value corporate cash less for firms that are expected to be sued in the near future.

It is well known that firms on average hold significant amounts of cash. Several studies, beginning with Opler, Pinkowitz, Stulz and Williamson (1999) show that firm characteristics cannot totally explain the large amount of cash held by firms on average. Our study identifies a new determinant of corporate cash holdings that is clearly related to the precautionary motive for accumulating large quantities of cash reserves. The results of this paper suggest that institutions, not just firm characteristics, interact with the costs and benefits of holding liquid assets. The empirical results also provide an insight into how firms manage risk in general. Firms appear to deal with litigation risks in an integrated manner, hedging the risk by both entering into limited insurance contracts and holding a larger cash buffer to offset the increased variability in expected cash flows, as suggested by Bolton, Chen and Wang (2011) and Froot and Stein (1998). 


\section{References}

Barber, B.M., Lyon, J.D., 1996, Detecting abnormal operating performance: the empirical power and specification of test-statistics. Journal of Financial Economics 41, 359-399.

Bates, T., Kahle, K. and R. Stulz, 2008. Why do U.S. firms hold so much more cash than they used to? Journal of Finance, 64, 1985-2021.

Bolton, P., H. Chen, and N. Wang, 2011. A unified theory of Tobin's q, corporate investment, financing, and risk management, forthcoming Journal of Finance.

Brown, S., Tucker, J., 2011. Large-sample evidence on firms' year-over-year MD\&A modifications, Journal of Accounting Research 49,309-346.

Cheng, C.S., Huang, H., Li ,Y., Lobo, G., 2010. Institutional monitoring through shareholder litigation, Journal of Financial Economics 95,356-383.

Choi, S.J., K.K. Nelson and A.C. Pritchard, 2009, The screening effect of the Private Securities Litigation Reform Act, Journal of Empirical Legal Studies 6, no. 1, 35-68.

Crane, A.D., 2011. The litigation environment of a firm and its impact on financial policy, working paper, Rice University.

Dittmar, A., and J. Mahrt-Smith, 2007. Corporate governance and the value of cash holdings. Journal of Financial Economics 83, 599-634.

Dyl, E.A., 1999. Estimating economic damages in class action securities fraud litigation. Journal of Forensic Economics, Vol. 12.

Engelmann, K. and B. Cornell, 1988, Measuring the cost of corporate litigation: Five case studies, Journal of Legal Studies 17, 377-399/

Erickson, Timothy, and T.M. Whited, 2005, Proxy-quality thresholds: Theory and applications, Financial Research Letters 2, 131-151.

Faulkender, M. and R. Wang, 2006. Corporate financial policy and the value of cash. Journal of Finance, 61, 1957-1990.

Field, L., Lowry, M., Shu, S., 2005. Does disclosure deter or trigger litigation? Journal of Accounting and Economics 39, 487-507.

Froot, K.A. and J.C. Stein, 1998. Risk management, capital budgeting, and capital structure policy for financial institutions: an integrated approach. Journal of Financial Economics, $47,55-82$. 
Gande, A. and C. M. Lewis, 2009. Shareholder initiated class action lawsuits: shareholder wealth effects and industry spillovers. Journal of Financial and Quantitative Analysis, 44, $823-850$.

Gompers, P., J. Ishii, and A. Metrick, 2003. Corporate governance and equity prices. Quarterly Journal of Economics 118, 107-155.

Gormley, T. and D. Matsa, 2009. Growing out of trouble? Legal liability and corporate responses to adversity, forthcoming Review of Financial Studies.

Harford, J., S.A. Mansi, and W.F. Maxwell, 2008. Corporate governance and firm cash holdings. Journal of Financial Economics 87(3):535-555..

Jones, C. L. and Weingram, S. E., 1996. The determinants of 10b-5 litigation risk, unpublished working paper, John M. Olin Program in Law and Economics, Stanford Law School, Stanford, CA.

Klausner, M. and J. Hegland, 2010, When are securities class actions dismissed, when do they settle, and for how much? - Part II, Professional Liability Underwriting Society Journal $23,1-5$.

Karpoff, J. M.; D. S. Lee; and G. S. Martin, 2008, The cost to firms of cooking the books. Journal of Financial and Quantitative Analysis, 43, 581-612.

Kim, C., Mauer, D.C., Sherman, A.E., 1998. The determinants of corporate liquidity: theory and evidence. Journal of Financial and Quantitative Analysis, 33, 305-334.

Kim, I.Y. and D.J. Skinner, 2012, Measuring securities litigation risk. emphJournal of Accounting and Economics, 53, 290-310.

Klasa, S., Maxwell, W.F., and H. Ortiz-Molina, 2009. The strategic use of corporate cash holdings in collective bargaining with labor unions. Journal of Financial Economics, Volume 92, Issue 3, 421-442.

Lie, E., 2001. Detecting abnormal operating performance: revisited. Financial Management, 30, 77-91.

Lins, K.V., H. Servaes, and P. Tufano, 2010, What drives corporate liquidity? An international survey of cash holdings and lines of credit, Journal of Financial Economics, 98, 160-176.

Lowry, M. and S. Shu, 2002. Litigation risk and IPO underpricing, Journal of Financial Economics, 309-336. 
Mikkelson, W., and M. Partch, 2003. Do persistent large cash reserves hinder performance? Journal of Financial and Quantitative Analysis, 38, 275-294.

Opler, T., Pinkowitz, L., Stulz, R., and R. Williamson, 1999. The determinants and implications of corporate cash holdings. Journal of Finance, 52, 3-46.

Peng, L. and A. Roell, 2008. Executive pay, earnings manipulation and shareholder lawsuits. Review of Finance, 12, 141-184.

Pinkowitz, L. and R. Williamson, 2007. What is the market value of a dollar of corporate cash?, Journal of Applied Corporate Finance, 19(3), 74-81.

Seetharaman, A., Gul, F., Lynn, S.,2002. Litigation risk and audit fees: evidence from UK firms cross-listed on US markets. Journal of Accounting and Economics 33, 1-115.

Shu, S., 2000. Auditor resignations: clientele effects and legal liability. Journal of Accounting and Economics 29, 173-205.

Skinner, D.J., 1994. Why firms voluntarily disclose bad news? Journal of Accounting Research 32, 38-60.

Skinner, D.J., 1997. Earnings disclosures and stockholder lawsuits. Journal of Accounting and Economics 23, 249-282.

Zingales, L., 2006. Is the U.S. capital market losing its competitive edge? Working paper, University of Chicago. 


\section{Table I}

\section{Distribution Litigation Events across Years and Industries}

The litigation sample consists of security class action lawsuits filed between 1996 and 2006 in which the defendant is a US corporation with data available on Compustat. Panel A reports the distribution of the sample lawsuits across years. Panel B reports the distribution of sued firms by various industries. Securities litigation data are from the Securities Class Action Clearinghouse website (http://securities.stanford.edu/) from 1996 to 2006.

\begin{tabular}{|c|c|}
\hline \multicolumn{2}{|c|}{ Panel A: Distribution of Lawsuits over Time } \\
\hline Year & Number of Lawsuits \\
\hline 1996 & 50 \\
\hline 1997 & 81 \\
\hline 1998 & 123 \\
\hline 1999 & 120 \\
\hline 2000 & 110 \\
\hline 2001 & 319 \\
\hline 2002 & 141 \\
\hline 2003 & 124 \\
\hline 2004 & 143 \\
\hline 2005 & 116 \\
\hline 2006 & 70 \\
\hline Total & 1,397 \\
\hline \multicolumn{2}{|c|}{ Panel B: Distribution of Lawsuits across Industries } \\
\hline Industry & Number of Lawsuits \\
\hline Agriculture and mining & 4 \\
\hline Apparel & 24 \\
\hline Communications, computers, and electronics & 555 \\
\hline Construction & 9 \\
\hline Finance & 169 \\
\hline Food & 15 \\
\hline Health & 37 \\
\hline Manufacturing & 175 \\
\hline Oil and Gas & 18 \\
\hline Printing and publishing & 9 \\
\hline Recreation & 15 \\
\hline Science & 83 \\
\hline Services & 78 \\
\hline Trade & 121 \\
\hline Transportation & 31 \\
\hline Utilities & 33 \\
\hline Other & 21 \\
\hline Total & 1,397 \\
\hline
\end{tabular}




\section{Table II}

\section{Lawsuit Resolution Statistics}

Panel A presents the outcomes of the lawsuits contained in our security class action litigation sample as of December 31, 2009. Panel B presents summary statistics related to the settlement amounts for the closed cases. For the statistics of "all non-pending cases" we assign a settlement amount equal to 0 to dismissed and withdrawn cases. Securities litigation data are from the Securities Class Action Clearinghouse website (http://securities.stanford.edu/) from 1996 to 2006.

\begin{tabular}{|c|c|c|c|c|c|}
\hline \multicolumn{6}{|c|}{ Panel A: Litigation Outcome } \\
\hline & Number of Cases & Percent of Total & & & \\
\hline Settled & 613 & $43.9 \%$ & & & \\
\hline Dismissed or withdrawn & 515 & $36.9 \%$ & & & \\
\hline Still pending & 269 & $19.3 \%$ & & & \\
\hline Total & 1,397 & & & & \\
\hline \multicolumn{6}{|c|}{ Panel B: Settlement Amount } \\
\hline & Mean & Median & $25^{\text {th }}$ Percentile & $75^{\text {th }}$ Percentile & Maximum \\
\hline \multicolumn{6}{|c|}{ Excluding Dismissed and Withdrawn Cases } \\
\hline Settlement ( $\$$ millions) & 56.4 & 6.5 & 3.0 & 19.3 & $3,200.0$ \\
\hline Settlement / Cash Holdings & $114.9 \%$ & $15.8 \%$ & $4.1 \%$ & $54.7 \%$ & $11,526.5 \%$ \\
\hline \multicolumn{6}{|l|}{ All Non-Pending Cases* } \\
\hline Settlement ( $\$$ millions) & 29.2 & 2.3 & 0.0 & 7.0 & $3,200.0$ \\
\hline Settlement / Cash Holdings & $59.6 \%$ & $4.3 \%$ & $0.0 \%$ & $27.8 \%$ & $11,526.5 \%$ \\
\hline
\end{tabular}

\footnotetext{
*In "all non-pending cases" we assign 0 to the settlement amount for dismissed and withdrawn cases.
} 


\section{Table III}

\section{Univariate Statistics: Cash Holdings in Event Time}

This table reports the distribution of cash holdings in event time for firms involved in securities litigation. Year zero is set as the year of the lawsuit initiation. Cash holdings are measured as the ratio of cash and short term investments to net-of-cash total assets. The sample period is 1996 to 2006.

\begin{tabular}{lccccc}
\hline \multicolumn{7}{c}{ Panel A: Cash Holdings in Event Time } \\
\hline Event Year & Mean & Q1 & Median & Q3 & Std. Dev. \\
\hline-2 & 0.224 & 0.029 & 0.120 & 0.364 & 0.241 \\
-1 & 0.223 & 0.029 & 0.130 & 0.369 & 0.241 \\
0 & 0.262 & 0.046 & 0.185 & 0.490 & 0.277 \\
1 & 0.249 & 0.044 & 0.157 & 0.408 & 0.245 \\
2 & 0.248 & 0.045 & 0.159 & 0.401 & 0.244 \\
\hline \multicolumn{7}{c}{ Panel B: Univariate Tests } \\
\hline Period & Mean Difference & SE Diff & t-statistic \\
\hline$(0)$ vs $(-2,-1)$ & 0.039 & 0.011 & 3.545 \\
$(1,2)$ vs $(-2,-1)$ & 0.025 & 0.009 & 2.778 \\
\hline
\end{tabular}


Table IV

\section{Class Action Litigation Events and Cash Holdings}

This dependent variable in all regressions is the ratio of cash and short-term investments to net-of-cash total assets. The firm characteristics, described in detail in the appendix, are also scaled by net-of-cash total assets. The litigation event time dummies, $L_{0}, L_{1}, L_{2}$, and $L_{3}$, are set equal to one in the year relative to the litigation event, with year zero being the year the litigation was initiated. The dummy variables for the placebo regression in specification (6) are defined in a similar manner as the litigation event dummies, but the event year is generated by a simple random sample with replacement among the overall Compustat sample such that the relative frequency of random events matches the relative frequency of actual litigation initiations each year in the full sample. $\mathrm{t}$ statistics are calculated based on robust standard errors clustered at the firm level. The sample period is 1996 to 2006.

\begin{tabular}{|c|c|c|c|c|c|c|}
\hline & (1) & (2) & (3) & (4) & (5) & (6) \\
\hline \multirow[t]{2}{*}{$L_{0}$} & 0.060 & 0.063 & 0.046 & 0.045 & 0.039 & -0.004 \\
\hline & $(3.96)^{* * *}$ & $(3.94)^{* * *}$ & $(2.82)^{* * *}$ & $(2.83)^{* * *}$ & $(3.29)^{* * *}$ & $(0.57)$ \\
\hline \multirow[t]{2}{*}{$L_{1}$} & 0.068 & 0.070 & 0.054 & 0.055 & 0.035 & -0.008 \\
\hline & $(4.38)^{* * *}$ & $(4.22)^{* * *}$ & $(3.15)^{* * *}$ & $(3.05)^{* * *}$ & $(2.42)^{* *}$ & (1.19) \\
\hline \multirow[t]{2}{*}{$L_{2}$} & 0.052 & 0.053 & 0.040 & 0.041 & 0.030 & 0.000 \\
\hline & $(3.39)^{* * *}$ & $(3.45)^{* * *}$ & $(2.61)^{* *}$ & $(2.67)^{* * *}$ & $(1.98)^{* *}$ & $(0.01)$ \\
\hline \multirow[t]{2}{*}{$L_{3}$} & 0.030 & 0.031 & 0.021 & 0.022 & 0.012 & -0.011 \\
\hline & $(1.94)^{*}$ & $(2.01)^{* *}$ & (1.37) & (1.43) & $(0.78)$ & (1.47) \\
\hline \multirow[t]{2}{*}{$\ln$ (Total Assets) } & -0.006 & -0.006 & -0.005 & -0.005 & -0.018 & -0.005 \\
\hline & $(3.10)^{* * *}$ & $(3.02)^{* * *}$ & $(2.37)^{* *}$ & $(2.56)^{* *}$ & $(6.07)^{* * *}$ & $(2.56)^{* *}$ \\
\hline \multirow[t]{2}{*}{ Leverage } & -0.272 & -0.269 & -0.234 & -0.232 & -0.134 & -0.232 \\
\hline & $(15.58)^{* * *}$ & $(15.58)^{* * *}$ & $(15.89)^{* * *}$ & $(15.73)^{* * *}$ & $(14.35)^{* * *}$ & $(15.95)^{* * *}$ \\
\hline \multirow[t]{2}{*}{ Cash Flow } & 0.067 & 0.066 & 0.059 & 0.059 & 0.037 & 0.058 \\
\hline & $(8.97)^{* * *}$ & $(8.39)^{* * *}$ & $(8.99)^{* * *}$ & $(8.74)^{* * *}$ & $(8.66)^{* * *}$ & $(8.60)^{* * *}$ \\
\hline \multirow[t]{2}{*}{ Net Working Capital } & -0.099 & -0.097 & -0.083 & -0.080 & -0.048 & -0.081 \\
\hline & $(7.91)^{* * *}$ & $(7.93)^{* * *}$ & $(7.10)^{* * *}$ & $(6.98)^{* * *}$ & $(7.33)^{* * *}$ & $(6.90)^{* * *}$ \\
\hline \multirow[t]{2}{*}{ Dividend Payer } & -0.049 & -0.049 & -0.023 & -0.024 & 0.007 & -0.025 \\
\hline & $(4.27)^{* * *}$ & $(4.25)^{* * *}$ & $(3.13)^{* * *}$ & $(3.13)^{* * *}$ & $(2.42)^{* *}$ & $(3.15)^{* * *}$ \\
\hline \multirow[t]{2}{*}{ Market-to-Book } & 0.008 & 0.008 & 0.007 & 0.007 & 0.004 & 0.006 \\
\hline & $(8.57)^{* * *}$ & $(8.22)^{* * *}$ & $(7.65)^{* * *}$ & $(7.48)^{* * *}$ & $(6.25)^{* * *}$ & $(7.68)^{* * *}$ \\
\hline \multirow[t]{2}{*}{ Capital Expenditures } & -0.480 & -0.480 & -0.428 & -0.418 & -0.319 & -0.418 \\
\hline & $(8.12)^{* * *}$ & $(8.25)^{* * *}$ & $(11.64)^{* * *}$ & $(11.56)^{* * *}$ & $(15.71)^{* * *}$ & $(11.44)^{* * *}$ \\
\hline \multirow[t]{2}{*}{ Acquisitions } & -0.425 & -0.432 & -0.415 & -0.415 & -0.280 & -0.419 \\
\hline & $(10.92)^{* * *}$ & $(10.28)^{* * *}$ & $(11.10)^{* * *}$ & $(10.65)^{* * *}$ & $(19.28)^{* * *}$ & $(10.46)^{* * *}$ \\
\hline \multirow[t]{2}{*}{ R\&D to Sales } & 0.075 & 0.075 & 0.059 & 0.059 & 0.018 & 0.059 \\
\hline & $(8.85)^{* * *}$ & $(8.17)^{* * *}$ & $(10.16)^{* * *}$ & $(10.46)^{* * *}$ & $(5.93)^{* * *}$ & $(10.85)^{* * *}$ \\
\hline \multirow[t]{2}{*}{ Net Equity Issuance } & 0.164 & 0.164 & 0.156 & 0.157 & 0.158 & 0.155 \\
\hline & $(16.94)^{* * *}$ & $(16.31)^{* * *}$ & $(15.99)^{* * *}$ & $(16.03)^{* * * *}$ & $(17.36)^{* * *}$ & $(15.53)^{* * *}$ \\
\hline \multirow[t]{2}{*}{ Net Debt Issuance } & 0.193 & 0.189 & 0.162 & 0.160 & 0.127 & 0.159 \\
\hline & $(11.41)^{* * *}$ & $(10.96)^{* * *}$ & $(11.91)^{* * *}$ & $(11.87)^{* * *}$ & $(12.53)^{* * *}$ & $(11.63)^{* * *}$ \\
\hline \multirow[t]{2}{*}{ Industry CF Volatility } & 0.521 & 0.579 & 0.082 & 0.040 & -0.025 & 0.049 \\
\hline & $(4.08)^{* * *}$ & $(3.75)^{* * *}$ & $(1.05)$ & $(0.42)$ & $(0.58)$ & $(0.52)$ \\
\hline Fixed Effects & & Year & Industry & Industry, Year & Firm, Year & Industry, Year \\
\hline Observations & 50,887 & 50,887 & 50,887 & 50,887 & 50,887 & 50,887 \\
\hline R-squared & 0.38 & 0.38 & 0.43 & 0.44 & 0.48 & 0.43 \\
\hline
\end{tabular}




\section{Table V}

\section{The Effects of Litigation on Peer Firms}

This table reports regression estimates from industry cash holdings regressions. Industry membership is based on 4-digit SIC codes. The firm characteristics, including cash holdings (which we describe in the appendix), are aggregated at the industry level on both an equal-weighted (EW) and value-weighted (VW) basis each year. Firms that are involved in actual litigation events are not included in the sample. The litigation dummy is set equal to one in years when a firm within the same 4-digit SIC industry has a lawsuit initiated against it in that calendar year. The last column reports the results using the value-weighted industry panel with firms from the communications, computers and electronics industries (SIC $=3570-3579,3600-3699,4800-4899,7370-7379)$ omitted from the sample. The sample period is 1996 to 2006 . The reported t-statistics are based on robust standard errors, clustered at the firm level in the firm-level panel and at the 4-digit SIC industry level for the aggregated industry panels.

\begin{tabular}{|c|c|c|c|c|}
\hline & Firm-Level Panel & EW Industry Panel & VW Industry Panel & TMT Firms Omitted \\
\hline \multirow[t]{2}{*}{ Industry Litigation Event } & 0.018 & 0.014 & 0.016 & 0.021 \\
\hline & $(2.61)^{* *}$ & $(3.72)^{* * *}$ & $(3.86)^{* * *}$ & $(4.17)^{* * *}$ \\
\hline \multirow[t]{2}{*}{$\ln$ (Total Assets) } & -0.005 & -0.005 & -0.005 & -0.004 \\
\hline & $(4.19)^{* * *}$ & $(1.33)$ & (1.39) & $(1.82)^{*}$ \\
\hline \multirow[t]{2}{*}{ Leverage } & -0.288 & -0.388 & -0.381 & -0.150 \\
\hline & $(14.92)^{* * *}$ & $(9.99)^{* * *}$ & $(9.68)^{* * *}$ & $(4.84)^{* * *}$ \\
\hline \multirow[t]{2}{*}{ Cash Flow } & 0.0770 & 0.135 & 0.147 & 0.204 \\
\hline & $(8.99)^{* * *}$ & $(3.70)^{* * *}$ & $(3.63)^{* * *}$ & $(3.99)^{* * *}$ \\
\hline \multirow[t]{2}{*}{ Net Working Capital } & -0.118 & -0.080 & -0.080 & -0.110 \\
\hline & $(6.51)^{* * *}$ & $(3.15)^{* * *}$ & $(3.18)^{* * *}$ & $(2.95)^{* * *}$ \\
\hline \multirow[t]{2}{*}{ Dividend Payer } & -0.050 & -0.071 & -0.071 & -0.021 \\
\hline & $(4.78)^{* * *}$ & $(4.07)^{* * *}$ & $(4.05)^{* * *}$ & $(0.24)$ \\
\hline \multirow[t]{2}{*}{ Market-to-Book } & 0.008 & 0.033 & 0.034 & 0.020 \\
\hline & $(6.45)^{* * *}$ & $(5.86)^{* * *}$ & $(5.91)^{* * *}$ & $(5.09)^{* * *}$ \\
\hline \multirow[t]{2}{*}{ Capital Expenditures } & -0.481 & 0.517 & 0.515 & -0.398 \\
\hline & $(8.48)^{* * *}$ & $(4.03)^{* * *}$ & $(4.00)^{* * *}$ & $(5.12)^{* * *}$ \\
\hline \multirow[t]{2}{*}{ Acquisitions } & -0.436 & -0.363 & -0.382 & -0.221 \\
\hline & $(10.57)^{* * *}$ & $(2.67)^{* * * *}$ & $(2.78) * * *$ & $(4.05)^{* * *}$ \\
\hline \multirow[t]{2}{*}{ R\&D to Sales } & 0.075 & 0.1121 & 0.1126 & 0.5353 \\
\hline & $(8.46)^{* * *}$ & $(6.22)^{* * *}$ & $(6.27)^{* * *}$ & $(5.69)^{* * *}$ \\
\hline \multirow[t]{2}{*}{ Net Debt Issuance } & 0.218 & 0.398 & 0.406 & 0.108 \\
\hline & $(10.97)^{* * *}$ & $(3.58)^{* * *}$ & $(3.65)^{* * *}$ & $(1.69)^{*}$ \\
\hline \multirow[t]{2}{*}{ Net Equity Issuance } & 0.187 & 0.896 & 0.906 & 0.200 \\
\hline & $(12.96)^{* * *}$ & $(8.07)^{* * *}$ & $(7.80)^{* * *}$ & $(3.22)^{* * *}$ \\
\hline \multirow[t]{2}{*}{ Industry CF Volatility } & 0.535 & 0.334 & 0.343 & 0.329 \\
\hline & $(3.57)^{* * *}$ & $(3.44)^{* * *}$ & $(3.49)^{* * *}$ & $(3.74)^{* * *}$ \\
\hline \multirow[t]{2}{*}{ Industry Stock Return } & 0.100 & 0.067 & 0.071 & 0.041 \\
\hline & $(6.15)^{* * *}$ & $(0.81)$ & $(0.82)$ & (1.37) \\
\hline Observations & 49,527 & 4,739 & 4,739 & 3,688 \\
\hline$R^{2}$ & 0.40 & 0.67 & 0.60 & 0.62 \\
\hline
\end{tabular}




\section{Table VI}

\section{Cash and Litigation Risk: Simultaneous Equations}

This table reports the estimation results for the following simultaneous equations model:

$$
\begin{aligned}
& \text { Insurance Effect : Cash Ratio }=\gamma_{1} \text { Litigation }+\theta_{1} X+\beta_{1} X_{1}+\varepsilon_{1}, \\
& \text { Enticement Effect }: \text { Litigation }=\gamma_{2} \text { Cash Ratio }+\theta_{2} X+\beta_{2} X_{2}+\varepsilon_{2},
\end{aligned}
$$

Cash Ratio is the ratio of cash and marketable securities to the book value of total assets for firm i; Litigation is the probability of litigation for firm $i ; X_{1}$ is leverage, the identifying variable of the first equation, and $X_{2}$ is stock turnover, the identifying variable of the second equation. Litigation risk is a dummy variable set equal to one for firms that are involved in a litigation in the following year and zero otherwise. Year and industry dummy variables are included in all specifications. The sample period is 1996 to 2006. 


\begin{tabular}{|c|c|c|c|c|c|c|}
\hline Second Stage & Cash Ratio & Litigation Risk & Cash Ratio & Litioation Risk & Cash Ratio & Litioation Risk \\
\hline Litigation Instrument & $\begin{array}{c}0.052 \\
(6.24) * * *\end{array}$ & & $\begin{array}{c}0.051 \\
(6.09) * * *\end{array}$ & & $\begin{array}{c}0.048 \\
(3.73)^{* * *}\end{array}$ & \\
\hline Cash Instrument & & $\begin{array}{l}-1.015 \\
(-1.28)\end{array}$ & & $\begin{array}{l}-1.022 \\
(-1.14)\end{array}$ & & $\begin{array}{l}-1.047 \\
(-1.02)\end{array}$ \\
\hline Leverage & $\begin{array}{c}-0.231 \\
(-10.73)^{* * *}\end{array}$ & & $\begin{array}{c}-0.229 \\
(-10.65)^{* * *}\end{array}$ & & $\begin{array}{c}-0.231 \\
(-3.23) * * *\end{array}$ & \\
\hline Turnover & & $\begin{array}{c}2.465 \\
(14.41)^{* * *}\end{array}$ & & $\begin{array}{c}2.457 \\
(14.31)^{* * *}\end{array}$ & & $\begin{array}{c}3.079 \\
(7.59)^{* * * *}\end{array}$ \\
\hline $\ln$ (Total Assets) & $\begin{array}{c}-0.019 \\
(-4.94) * * *\end{array}$ & $\begin{array}{c}0.206 \\
(9.76)^{* * * *}\end{array}$ & $\begin{array}{c}-0.019 \\
(-4.79)^{* * * *}\end{array}$ & $\begin{array}{c}0.212 \\
(9.95)^{* * * *}\end{array}$ & $\begin{array}{c}-0.025 \\
(-2.10)^{* *}\end{array}$ & $\begin{array}{c}0.267 \\
(5.65)^{* * * *}\end{array}$ \\
\hline Cash Flow & $\begin{array}{c}-0.014 \\
(-3.81)^{* * *}\end{array}$ & $\begin{array}{c}-0.072 \\
(-2.48)^{* *}\end{array}$ & $\begin{array}{c}-0.014 \\
(-3.80)^{* * * *}\end{array}$ & $\begin{array}{c}-0.075 \\
(-2.53)^{* *}\end{array}$ & $\begin{array}{l}-0.010 \\
(0.56)\end{array}$ & $\begin{array}{l}-0.107 \\
(-1.81)^{*}\end{array}$ \\
\hline Net Working Capital & $\begin{array}{l}-0.004 \\
(-0.76)\end{array}$ & $\begin{array}{l}-0.004 \\
(-0.10)\end{array}$ & $\begin{array}{l}-0.003 \\
(-0.53)\end{array}$ & $\begin{array}{l}0.024 \\
(0.61)\end{array}$ & $\begin{array}{l}-0.014 \\
(-0.98)\end{array}$ & $\begin{array}{l}0.121 \\
(1.71)\end{array}$ \\
\hline Dividend Payer & $\begin{array}{c}-0.049 \\
(-3.63)^{* * *}\end{array}$ & $\begin{array}{c}-0.341 \\
(-3.64)^{* * *}\end{array}$ & $\begin{array}{c}-0.049 \\
(-3.65)^{* * *}\end{array}$ & $\begin{array}{c}-0.337 \\
(-3.58)^{* * *}\end{array}$ & $\begin{array}{c}-0.055 \\
(-1.96)^{*}\end{array}$ & $\begin{array}{c}-0.458 \\
(-2.65)^{* * *}\end{array}$ \\
\hline Market-to-Book & $\begin{array}{c}0.010 \\
(7.79)^{* * *}\end{array}$ & $\begin{array}{l}0.001 \\
(0.06)\end{array}$ & $\begin{array}{c}0.010 \\
(7.82)^{* * *}\end{array}$ & $\begin{array}{l}0.001 \\
(0.12)\end{array}$ & $\begin{array}{c}0.019 \\
(3.89)^{* * *}\end{array}$ & $\begin{array}{l}0.037 \\
(0.86)\end{array}$ \\
\hline Capital Expenditures & $\begin{array}{c}-0.470 \\
(-7.63) * * *\end{array}$ & $\begin{array}{l}-0.116 \\
(-0.21)\end{array}$ & $\begin{array}{c}-0.466 \\
(-7.60)^{* * *}\end{array}$ & $\begin{array}{l}-0.151 \\
(-0.28)\end{array}$ & $\begin{array}{c}-0.667 \\
(-3.47) * * *\end{array}$ & $\begin{array}{l}-0.045 \\
(-0.56)\end{array}$ \\
\hline Acquisitions & $\begin{array}{c}-0.658 \\
(-9.41)^{* * *}\end{array}$ & $\begin{array}{l}0.096 \\
(0.15)\end{array}$ & $\begin{array}{c}-0.658 \\
(-9.48)^{* * *}\end{array}$ & $\begin{array}{l}-0.080 \\
(-0.12)\end{array}$ & $\begin{array}{c}-0.619 \\
(-3.52) * * *\end{array}$ & $\begin{array}{l}-0.721 \\
(-0.10)\end{array}$ \\
\hline R\&D to Sales & $\begin{array}{c}0.094 \\
(14.10) * * *\end{array}$ & $\begin{array}{c}0.192 \\
(2.44)^{* *}\end{array}$ & $\begin{array}{c}0.093 \\
(14.16)^{* * *}\end{array}$ & $\begin{array}{c}0.208 \\
(2.60) * * *\end{array}$ & $\begin{array}{l}0.083 \\
(1.58)\end{array}$ & $\begin{array}{c}0.711 \\
(2.28)^{* *}\end{array}$ \\
\hline Net Debt Issuance & $\begin{array}{c}0.260 \\
(7.07)^{* * *}\end{array}$ & $\begin{array}{c}-0.780 \\
(-3.20)^{* * *}\end{array}$ & $\begin{array}{c}0.260 \\
(7.13)^{* * *}\end{array}$ & $\begin{array}{c}-0.731 \\
(-2.95) * * *\end{array}$ & $\begin{array}{c}0.271 \\
(2.30)^{* *}\end{array}$ & $\begin{array}{c}-1.446 \\
(-2.60) * * *\end{array}$ \\
\hline Net Equity Issuance & $\begin{array}{c}0.205 \\
(11.24) * * *\end{array}$ & $\begin{array}{l}-0.022 \\
(-0.12)\end{array}$ & $\begin{array}{c}0.205 \\
(11.36)^{* * *}\end{array}$ & $\begin{array}{l}0.023 \\
(0.12)\end{array}$ & $\begin{array}{l}0.142 \\
(1.18)\end{array}$ & $\begin{array}{l}0.360 \\
(0.55)\end{array}$ \\
\hline Industry CF Volatility & $\begin{array}{c}0.123 \\
(7.10) * * *\end{array}$ & $\begin{array}{l}-0.025 \\
(-0.15)\end{array}$ & $\begin{array}{c}0.118 \\
(6.30) * * *\end{array}$ & $\begin{array}{l}-0.130 \\
(-0.79)\end{array}$ & $\begin{array}{l}0.026 \\
(0.61)\end{array}$ & $\begin{array}{l}-0.245 \\
(-0.91)\end{array}$ \\
\hline Systematic Volatility & $\begin{array}{l}0.163 \\
(1.05)\end{array}$ & $\begin{array}{l}0.950 \\
(0.71)\end{array}$ & $\begin{array}{l}0.161 \\
(1.04)\end{array}$ & $\begin{array}{l}0.955 \\
(0.69)\end{array}$ & $\begin{array}{c}3.124 \\
(1.73)^{*}\end{array}$ & $\begin{array}{l}0.907 \\
(0.64)\end{array}$ \\
\hline Idiosyncratic Volatility & $\begin{array}{l}-0.079 \\
(-0.37)\end{array}$ & $\begin{array}{c}10.368 \\
(7.16)^{* * * *}\end{array}$ & $\begin{array}{l}-0.086 \\
(-0.40)\end{array}$ & $\begin{array}{c}10.488 \\
(7.18)^{* * * *}\end{array}$ & $\begin{array}{l}-0.421 \\
(-0.35)\end{array}$ & $\begin{array}{c}17.157 \\
(3.30)^{* * * *}\end{array}$ \\
\hline Unionization Rate & & & $\begin{array}{c}0.000 \\
(-0.57)\end{array}$ & $\begin{array}{c}-0.010 \\
(-2.65)^{* * *}\end{array}$ & & \\
\hline Missing Unionization Dummy & & & $\begin{array}{l}-0.024 \\
(-1.21)\end{array}$ & $\begin{array}{l}-0.154 \\
(-1.13)\end{array}$ & & \\
\hline G-Index & & & & & $\begin{array}{l}-0.002 \\
(-0.43)\end{array}$ & $\begin{array}{l}-0.026 \\
(-1.17)\end{array}$ \\
\hline Ownership & & & & & $\begin{array}{l}0.000 \\
(0.25)\end{array}$ & $\begin{array}{l}0.006 \\
(0.82)\end{array}$ \\
\hline $\begin{array}{l}\text { Adj. } R^{2} \\
\text { Pseudo } R^{2}\end{array}$ & 0.510 & 0.195 & 0.510 & 0.197 & 0.494 & 0.173 \\
\hline $\mathrm{N}$ & 2,413 & 2,413 & 2,413 & 2,413 & 717 & 717 \\
\hline
\end{tabular}




\section{Table VII}

\section{Litigation Risk and Corporate Investment}

This table presents the estimation results from the investment regression

$$
I_{i t}=\alpha_{i}+\beta_{1} \text { Litigation }_{i t}+\beta_{2} Q_{i, t-1}+\beta_{3} C F_{i, t-1}+\gamma_{t}+\varepsilon_{i t},
$$

where $I_{i t}$ is capital expenditures scaled by beginning-of-year net property, plant and equipment, $Q_{i, t-1}$ is beginning-of-year Tobin's $Q$, and $C F_{i, t-1}$ is the beginning-of-year cash flow rate. In the first two columns of the table, the variable Litigation $i t$ is a dummy variable set equal to one if a litigation is filed against firm $i$ in year $t$, and zero otherwise. In the last column, the litigation dummy is set equal to one if there is a litigation event involving a peer firm in firm $i$ 's industry, where industry classification is based on four-digit SIC codes. Standard errors are clustered by firm and the resulting $t$-statistics are reported in parentheses.

\begin{tabular}{lccc}
\hline & \multicolumn{2}{c}{ Own Firm Litigations } & Peer Firm Litigation \\
\hline Litigation Dummy & -0.157 & -0.127 & -0.022 \\
& $(8.19)^{* * *}$ & $(6.82)^{* * *}$ & $(2.86)^{* * *}$ \\
$Q_{I, t-1}$ & 0.034 & 0.031 & 0.036 \\
& $(12.40)^{* * *}$ & $(11.35)^{* * *}$ & $(13.62)^{* * *}$ \\
$C F_{I, t-1}$ & 0.223 & 0.201 & 0.232 \\
& $(15.31)^{* * *}$ & $(13.75)^{* * *}$ & $(16.49)^{* * *}$ \\
Constant & 0.405 & 0.293 & 0.406 \\
& $(59.81)^{* * *}$ & $(14.93)^{* * *}$ & $(58.27)^{* * *}$ \\
\hline Fixed Effects & Firm & Firm, Year & Firm, Year \\
Observations & 49,527 & 50,887 & 50,887 \\
R-squared & 0.06 & 0.07 & 0.06 \\
\hline
\end{tabular}




\section{Table VIII}

\section{The Effect of Litigation Risk on the Value of Cash}

This table presents the results of OLS regressions in which the independent variable is the excess stock return (the firm's fiscal year stock return minus the matched Fama and French $5 \times 5$ portfolio's return). All dependent variables except Leverage, Litigation, Unionization Rate, and Missing Unionization Rate are deflated by the lagged market value of equity. Cash Holdings is cash plus marketable securities, Litigation is the in-sample predicted probability from the probit model reported in Table VIII, Earnings is earnings before extraordinary items plus interest, deferred tax credits, and investment tax credits, and Net Assets is total assets minus cash holdings. Dividends are measured as common dividends paid, and Net Financing is the total equity issuance minus repurchases plus debt issuance minus debt redemption. R\&D Expenses are $\mathrm{s}$ et to zero if missing and Repurchases is defined as the percentage of distributions to shareholders that occur in the form of repurchases. $\Delta X$ is compact notation for the 1-year change, $X_{t}-X_{t-1}$. The subscript $t-1$ means the value of the variable is at the end of fiscal year $t-1$. The second and third regressions are only on the subset of firms with positive payout in the corresponding fiscal year. Standard errors are clustered at the firm level and t-statistics are reported in parentheses.

\begin{tabular}{|c|c|c|c|}
\hline & (1) & (2) & (3) \\
\hline$\Delta$ Cash Holdings & $\begin{array}{c}1.246 \\
(13.46)^{* * *}\end{array}$ & $\begin{array}{c}1.198 \\
(12.29) * * *\end{array}$ & $\begin{array}{c}1.267 \\
(6.73)^{* * *}\end{array}$ \\
\hline Litigation & $\begin{array}{c}-2.074 \\
(-18.83)^{* * *}\end{array}$ & $\begin{array}{c}-2.078 \\
(-18.40)^{* * *}\end{array}$ & $\begin{array}{c}-1.870 \\
(-17.26)^{* * * *}\end{array}$ \\
\hline Litigation $\times \Delta$ Cash Holdings & $\begin{array}{c}-1.146 \\
(-2.31)^{* *}\end{array}$ & $\begin{array}{c}-1.293 \\
(-2.42)^{* *}\end{array}$ & $\begin{array}{c}-0.973 \\
(-1.79)^{*}\end{array}$ \\
\hline$\Delta$ Earnings & $\begin{array}{c}0.272 \\
(4.68)^{* * *}\end{array}$ & $\begin{array}{c}0.271 \\
(4.68)^{* * *}\end{array}$ & $\begin{array}{c}0.384 \\
(7.42)^{* * *}\end{array}$ \\
\hline$\Delta$ Net Assets & $\begin{array}{c}0.088 \\
(3.44)^{* * * *}\end{array}$ & $\begin{array}{c}0.087 \\
(3.43) * * *\end{array}$ & $\begin{array}{c}0.086 \\
(3.61)^{* * * *}\end{array}$ \\
\hline$\Delta \mathrm{R} \& \mathrm{D}$ Expenses & $\begin{array}{l}-0.516 \\
(-1.06)\end{array}$ & $\begin{array}{l}-0.517 \\
(-1.07)\end{array}$ & $\begin{array}{l}-0.932 \\
(-1.96)^{*}\end{array}$ \\
\hline$\Delta$ Interest Expense & $\begin{array}{c}-0.904 \\
(-3.89) * * *\end{array}$ & $\begin{array}{c}-0.902 \\
(-3.89)^{* * *}\end{array}$ & $\begin{array}{c}-1.325 \\
(-6.41)^{* * *}\end{array}$ \\
\hline$\Delta$ Dividends & $\begin{array}{l}1.152 \\
(1.31)\end{array}$ & $\begin{array}{l}1.147 \\
(1.30)\end{array}$ & $\begin{array}{l}1.465 \\
(1.56)\end{array}$ \\
\hline Cash Holdings $_{t-1}$ & $\begin{array}{c}0.155 \\
(7.30)^{* * *}\end{array}$ & $\begin{array}{c}0.155 \\
(7.22)^{* * *}\end{array}$ & $\begin{array}{c}0.148 \\
(7.18)^{* * * *}\end{array}$ \\
\hline Market Leverage & $\begin{array}{c}-0.868 \\
(-15.10)^{* * *}\end{array}$ & $\begin{array}{c}-0.876 \\
(-15.21)^{* * *}\end{array}$ & $\begin{array}{c}-0.722 \\
(-11.96)^{* * *}\end{array}$ \\
\hline Net Financing & $\begin{array}{c}-0.042 \\
(-2.67)^{* * *}\end{array}$ & $\begin{array}{c}-0.042 \\
(-2.70) * * *\end{array}$ & $\begin{array}{c}-0.035 \\
(-2.31)^{* *}\end{array}$ \\
\hline Cash Holdings $_{t-1} \times \Delta$ Cash Holdings & $\begin{array}{c}-0.084 \\
(-2.43)^{* *}\end{array}$ & $\begin{array}{c}-0.085 \\
(-2.42)^{* *}\end{array}$ & $\begin{array}{c}-0.061 \\
(-2.44)^{* *}\end{array}$ \\
\hline Leverage $\times \Delta$ Cash Holdings & $\begin{array}{c}-1.667 \\
(-5.93) * * *\end{array}$ & $\begin{array}{c}-1.642 \\
(-5.67) * * *\end{array}$ & $\begin{array}{c}-1.271 \\
(-4.53)^{* * *}\end{array}$ \\
\hline Unionization Rate & & $\begin{array}{l}0.001 \\
(0.26)\end{array}$ & \\
\hline Unionization Rate $\times \Delta$ Cash Holdings & & $\begin{array}{l}-0.002 \\
(-0.33)\end{array}$ & \\
\hline Missing Unionization Rate & & $\begin{array}{l}-0.035 \\
(-1.18)\end{array}$ & \\
\hline G-Index & & & $\begin{array}{l}-0.002 \\
(-0.73)\end{array}$ \\
\hline G-Index $\times \Delta$ Cash Holdings & & & $\begin{array}{c}-0.045 \\
(-2.72)^{* * *} \\
\end{array}$ \\
\hline $\mathrm{N}$ & 12,656 & 12,656 & 11,195 \\
\hline Adjusted $R^{2}$ & 0.17 & 0.17 & 0.15 \\
\hline
\end{tabular}


DATA APPENDIX

\begin{tabular}{|c|c|c|}
\hline Variable & Definition & Source \\
\hline $\ln$ (Total Assets) & Natural logarithm of the book value of assets in 1994 dollars & Compustat \\
\hline Leverage & (Long-term debt+short-term debt)/book value of assets. & Compustat \\
\hline Cash Flow & Earnings after interest, dividends, and taxes, and before depreciation, divided by net assets & Compustat \\
\hline Net Working Capital & Net working capital minus cash, divided by assets & Compustat \\
\hline Dividend Payer & Indicator set equal to one in years in which a firm pays dividends & Compustat \\
\hline Market-to-Book & Ratio of the market value to the book value of a firm's assets & Compustat \\
\hline Capital Expenditures & Capital expenditures divided by assets & Compustat \\
\hline Acquisitions & Acquisition expenditures divided by assets & Compustat \\
\hline $\mathrm{R} \& \mathrm{D}$ to Sales & Research and Development expenses divided by sales; set to zero if missing & Compustat \\
\hline Net Debt Issuance & Debt issuance minus debt retirement divided by assets & Compustat \\
\hline Net Equity Issuance & Equity sales minus equity purchases divided by assets & Compustat \\
\hline Industry CF Volatility & 2-SIC code industry average of firms' cash flow standard deviations for the previous 20 years & Compustat \\
\hline \multirow[t]{2}{*}{ Litigation Dummy } & Set equal to one when firms are involved in a class action lawsuits in the same year. & SCAC* $^{*}$ \\
\hline & The dummy mantains the same value also in the two years following the litigation & \\
\hline Litigation Risk Dummy & Set equal to one when firms are involved in a class action lawsuits in the following year & SCAC \\
\hline Unionization Rate & Fraction of workers in a 3-digit CIC industry that are represented by unions & www.unionstats.com \\
\hline Missing Unionization Dummy & Set equal to one when unionization rate data is missing & \\
\hline Stock Turnover & {$\left[1-\prod_{t=1}^{365}\left(1-\right.\right.$ volume $\operatorname{traded}_{t} /$ total shares $\left.\left.t\right)\right]$, for the one-year period preceding the lawsuit filing } & CRSP \\
\hline Industry Stock Return & Value weighted average industry returns for the year preceding the litigation filing & CRSP \\
\hline Cash Holdings & Cash plus marketable securities & Compustat \\
\hline Repurchases & Percentage of distributions to shareholders that occur in the form of repurchases & Compustat \\
\hline Earnings & Earnings before extraordinary items plus interest & Compustat \\
\hline Net Assets & Total assets minus cash holdings & Compustat \\
\hline R\&D Expenses & Research and Development expenses; set to zero if missing & Compustat \\
\hline Net Financing & Total equity issuance minus repurchases plus debt issuance minus debt redemption & Compustat \\
\hline Dividends & Common dividends paid & Compustat \\
\hline Market Leverage & Total debt divided by total debt plus the market value of equity & Compustat \\
\hline Idiosyncratic Risk & Measured as the standard deviation of residuals from a regression of excess daily returns on the market factor & CRSP \\
\hline Systematic Risk & Standard deviation of predicted values from regression of excess daily returns on the market factor & CRSP \\
\hline
\end{tabular}

*Securities Class Action Clearinghouse 